\title{
力覚提示機能を有する低侵襲外科手術支援ロボット Surgical robot for minimally invasive surgery with force perception
}

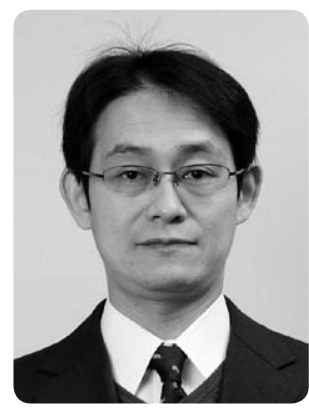

川嶋 健嗣

Kenji Kawashima

東京医科歯科大学 生体材料工学研究所

Institute of Biomaterials and Bioengineering, Tokyo Medical and Dental University

近年，外科手術において手術支援ロボットの導入が進んでいる。著者らは東京工業大学ならびに東 京医科歯科大学発ベンチャー企業リバーフィールド株式会社を設立し, 空気圧を用いた超精密制御技 術に関する研究成果を活かした空気圧駆動型手術支援ロボットの開発を行っている。本発表では，マ スタスレーブ型の手術支援ロボットシステムの国内外での開発状況，著者らが開発を進めているシス テムならびにそこから派生した内視鏡を保持操作するロボットを紹介する。

空気圧駆動は軽量で柔らかさを有する, 直接駆動で比較的大きな力を発生可能, クリーンで取り扱 いが容易などの利点がある。これらの利点に着目して，鉗子駆動に空気圧を採用し，鉗子先端にかか る外力を鉗子根元に配置した空気圧シリンダの内圧変化から検出可能な機能を提案，実装している。 現在市販されている da Vinci は視覚のみの操作に頼っている。これに対して提案しているシステム では力覚提示機能を有しており，手術の安全性向上に寄与することが期待される。

ハンドヘルド型のロボット鉗子は，鉗子先端に屈曲 2 関節と把持機能を有しており，鉗子根元に配 置した 4 本の空気圧シリンダでワイアを引っ張ることで屈曲を実現している。鉗子が屈曲した状態で 握り手を回すと, 通常は鉗子の軸を中心とした回転運動になるが, 本ロボット鉗子は, 屈曲した鉗子 先端を軸とした回転を実現する制御を提案，実装している。これにより，縫合などの作業が容易にな る利点がある。in vitro 実験による有効性を示す。

手術支援ロボットシステムから派生した内視鏡操作システムは，空気圧駆動によって柔らかな動作 を実現している。頭部にジャイロセンサーを装着した執刀医が，頭を上下・左右に傾けると，その動 きを感知して, 空気圧で内視鏡を動作させる。内視鏡の抜き差し（前後），上下，左右，そして回転 の 4 つの自由度を有しており，頭部の動きと足元のスイッチを組み合わせて制御する。大学発ベン チャー企業から実用化し，臨床での使用が始まっている。 


\section{略 歴}

[経 歴]

1992 年 東京工業大学工学部 制御工学科 卒業

1997 年 東京工業大学大学院理工学研究科 制御工学専攻 博士後期課程修了

1997 年 東京都立工業高等専門学校 機械工学科 助手

2000 年 東京工業大学 精密工学研究所 助教授

2007 年 2008 年

ワシントン大学 電気工学科 バイオロボティクス研究室客員研究員 兼務

2009 年〜 2011 年

内閣府 上席政策調査員 兼務

2013 年 東京医科歯科大学 生体材料工学研究所 教授

現在に至る

2014 年 大学発ベンチャー企業リバーフィールド（株）設立 現在取締役兼務

[主な研究分野]

医用システム, ロボット工学, 人間機械システム

[主な学会活動]

日本フルードパワーシステム学会 理事

日本コンピュータ外科学会 評議員

日本内視鏡外科学会, 日本機械学会, 計測自動制御学会, 精密工学会などの会員 